\title{
Feminism is Love: Structural, Romantic, and Marxist-Feminist Themes in Pride and Prejudice and Les Misérables
}

\section{Chutian Weng}

Department of English, River Hill, Maryland, United States of America chutianweng@gmail.com

\begin{abstract}
Despite the socially constrictive societies they each lived in, Jane Austen and Victor Hugo demonstrate that Marxist-feminist and related egalitarian beliefs result in stronger romantic relationships. Through the beliefs, actions, and ultimate fates of their characters, Austen and Hugo advocate for matrimonial and broader societal reform. The relationship between feminism and love present in two of the authors' major works-Pride and Prejudice and Les Misérables_can best be examined by comparing the relationships of feminist couples to those of conforming couples; Elizabeth and Darcy or Marius and Cosette are more feminist and have a stronger relationship than Charlotte and Collins or Jane and Bingley. Ultimately, this research implies that relationships founded on the basis of equality and mutual respect are stronger than those which are not.
\end{abstract}

Keywords_romantic relationships, feminism, Marxism, Pride and Prejudice, Les Misérables

\section{INTRODUCTION}

Authors, scholars, and literary critics throughout history have long noted the idea of the tradition-defying romantic couple. The interconnectedness of love and defiance is especially present as a theme throughout Western literature. While a vast number of works include the theme to some extent, in this research, two relatively different works, Jane Austen's Pride and Prejudice and Victor Hugo's Les Misérables, including its Broadway musical production, will be analyzed from a feminist and quasiMarxist lens. This research concept stems from the observation that Mr. Darcy's love for Elizabeth in Pride and Prejudice grew alongside her increasingly bold behavior, and that the ultimate fate of couples in both novels is a function of their Marxist-feminist ideology. Furthermore, both Austen and Hugo (and the creators of the Les Misérables musical) subtly advocate in favor of these ideologies by determining the final condition of the characters who express or fail to express these ideals. Because fiction authors are the creators of their worlds, they are able to manipulate the fate of their characters as they wish, in effect rewarding characters or couples for their behaviors or beliefs. The Thénardiers, despite their amorality, are an equal partnership and are rewarded by escaping punishment for their scams; however, Fantine is financially dependent on her husband and is punished in the form of the husband leaving and the relationship dissolving. In Pride and Prejudice, Elizabeth and Darcy's forthrightness with each other allows them to avoid the near failure that Jane and Bingley undergo. The correlation between Marxist-feminist ideals and the strength of romantic relationships in Pride and Prejudice and Les Misérables is best exemplified by contrasting the actions and behaviors of barrier-breaking romantic couples with those of traditional, socially conforming partners.

\subsection{Introduction to Pride and Prejudice}

Jane Austen's Pride and Prejudice was published in 1813, nearly six years after she first began writing the novel. In some ways, her novel reflects her world and the English society she lived in-the emphasis on acquiring or maintaining wealth through marriage, for instance, was a very real concern for many members of the higher levels of society. This social class, often referred to as the "landed gentry," was below the aristocracy, but still able to live comfortably and raise an income without labor by leasing their land to country farmers (Chicago Public Library, 2005). Also true was the upper-class stigma against working for a living; even wealthy professionals and merchants were considered of a lower social class than the landed gentry because they derived their income from labor (Howard, 2004). What was less apparent in Austen's novel, however, was the political turmoil of the time. While Austen's characters live a relatively peaceful life at home and in the surrounding country, Britain was frequently at war, and the "first whispers of feminist and 
abolitionist concerns" (Chicago Public Library, 2005, para. 4) were being heard in Europe. Some of this feminism could be seen in Austen's own life-her first novel, Sense and Sensibility, was published with an inscription on the title page noting that the book was "By a Lady," a parting from the traditional male voices in Regency England's literary sphere.

\subsection{Introduction to Les Misérables}

The history of Les Misérables is much more rooted in the real world. Victor Hugo wrote the novel during his 1850s exile after he denounced the French Napoleon III's declaration of emperorship. Despite Hugo's criticism of social institutions (absolute monarchy in particular), the 1980 musical adaptation and 2012 musical film both focus more on the individual passions and conflicts that shaped the story (Gossard, 2013). Centered around the events of the June Rebellion of 1832, Les Misérables and its themes of justice and redemption seem to be unrelated to a discussion about feminism. However, it is this feature of the work that makes it useful in this research-it is a means of showing that, even while pushing for broad social reform, visionary authors such as Hugo may still hold Marxist-feminist beliefs alongside authors such as Austen. This research and subsequent discussion will focus on the original novel by Victor Hugo, as well as the stage musical (Boublil, Natel, Schönberg, \& Taylor, 1995) and the 2012 film (Bevan, Fellner, Hayward, Mackintosh, \& Hooper, 2012).

\section{FEMINISM AND CLASSISM IN INDIVIDUAL CHARACTERS}

\subsection{Pride and Prejudice}

One divisive factor among the characters in Pride and Prejudice is that of matrimony. Marriage in Regency England was "considered one of the basic institutions of [the] social structure" (Awan \& Ambreen, 2018, p. 668), and along with other social institutions, it was used for socioeconomic purposes. From a modern perspective, marrying for anything but love seems irrational, or, at least, not ideal; for the gentry of Regency England, however, marrying for economic reasons was encouraged. The opening lines of the novel reflect the perceived necessity of the financially-motivated marriage:

It is a truth universally acknowledged, that a single man in possession of a good fortune must be in want of a wife. However little known the feelings or views of such a man may be on his first entering a neighbourhood, this truth is so well fixed in the minds of the surrounding families, that he is considered as the rightful property of some one or other of their daughters.

(Austen, 2003, p. 5)

Marrying for wealth rather than love was no fault of the people, but rather a shortcoming of the society they lived in. Oftentimes, women were financially dependent on men. From a purely Marxist point of view, the men were the primary economic instruments, or the bourgeoisie, and thus wielded power over the rest of society. This power is evidenced by the entailment of Mr. Bennet's estate to Mr. Collins, the closest male heir, rather than Mr. Bennet's being able to pass his land down to his own daughters. Even if a woman had property or some wealth of her own, it was common practice for wives to give control of their wealth to their husbands following their marriage (Awan \& Ambreen, 2018). The fact that women were financially dependent on men changed their relationship - marriage could very rarely be based on love, and instead must be primarily based on the prospect of financial support. Indeed, scholars argue that women in Pride and Prejudice were thus evaluated for their beauty, and men for their wealth (Bajaj, 2017). One could argue that men were confined to this system, too, as judgments were made about them from only their wealth. Elizabeth certainly noted this prejudice or bias of sorts when the ballroom saw Darcy as a "fine, tall person, [with] handsome features, [and a] noble mien" upon hearing of his having "ten thousand a-year" (Austen, 2003, p. 12). But from a Marxist perspective, men are not confined to this system at all, or at least not in the same way women are. Because men typically had control of the money, they essentially dominated the economy and were able to escape or change the system if they wished. Instead of favoring a more egalitarian socioeconomic structure, the richest and most powerful perpetuated the practice of loveless marriage.

The primary female characters in Pride and Prejudice have differing views on matrimony-Elizabeth echoes the modern idea of marrying out of love and maintaining one's core identity, while Jane, Charlotte, and Caroline Bingley all conform to the social norms for women regarding marriage. By marrying Mr. Collins to maintain her status as a relatively well-off member of the gentry, Charlotte exemplifies the typical marriage of the time. However, in doing so, Charlotte sacrifices her judgment of character and some of her own values (Chang, 2014). While standard, this sacrifice, even though it is made by one of her closest friends, is one that Elizabeth 
herself would find unacceptable. She makes no effort to hide her surprise at Charlotte's marriage, exclaiming, "Engaged to Mr. Collins! my dear Charlotte, impossible!" (Austen, 2003, p. 124). Even with extremely limited financial opportunities - either marry rich or be forced to work for a living due to the entailment (Bajaj, 2017)Elizabeth chooses her beliefs over those of society, as evidenced by her rejection of Mr. Collins's proposal and Mr. Darcy's first proposal. Interestingly, despite these highly unconventional rejections, Elizabeth does not resist the entailment of her family's estate. Perhaps, then, Elizabeth (and Austen) advocate not necessarily for sweeping, radical social reform, but rather for taking the first steps towards a more just society.

Even though Jane is Elizabeth's sister, Jane does not share the boldness of Elizabeth's words and actions. In fact, Jane submits to the social expectation that women should appear emotionally moderate, displaying only a fraction of their affection, if at all. However, the consequences of her actions demonstrate that conforming to male-perpetuated idea of the "perfect woman" will fail-in his letter to Elizabeth, Darcy describes how Jane's "looks and manners were open, cheerful, and engaging as ever, but without any symptom of particular regard" (Austen, 2003, p. 195). Even Elizabeth agrees that "Jane's feelings, though fervent, were little displayed" (p. 205), causing Darcy to believe that Jane was indifferent to Bingley. Jane's complaisance thus has the effect of nearly ruining her relationship with Bingley.

However, Jane and Charlotte are not the only characters who conform; despite Caroline Bingley's mannerisms, she, too, allows her mindset to be determined by what she perceives to be the social norm. Caroline attempts to gain Darcy's favor by echoing his views and behaviors. She assumes an interest in reading only because Darcy does, demonstrating her willingness to change herself for his sake. Her actions reflect the notion that the values of men were what mattered in society, and that women should mold themselves to fit those values (Chang, 2014). Ironically, Caroline criticizes Elizabeth for being "one of those young ladies who seek to recommend themselves to the other sex by undervaluing their own" (Austen, 2003, p. 41), but in reality, that description best suits herself. Caroline, Jane, and Charlotte each represent an aspect of the "traditional Regency-era woman" (Chang, 2014 , p. 82), one willing to change themselves to please men. Though Elizabeth's actions may be normal in today's world, they were, at the very least, highly unconventional in hers.

The expectations each of these characters have of themselves and of women in general also indicates their differences. Due to their relative social statuses, society held men and women to different personal and moral standards. Not only were women expected to conform, but they were also expected to reach an impossibly high bar to be considered "accomplished." H. C. Chang (2014) observes that the conversation between Darcy, Elizabeth, and Caroline about what constitutes female accomplishment is highly distinctive of the morals that set Elizabeth apart from the others. Caroline and Darcy believe that a "woman must have a thorough knowledge of music, singing, drawing, dancing, and the modern languages" (Austen, 2003, p. 40) in order to be considered accomplished. On the other hand, men in Regency England could get by happily simply by being wealthy and kind, as Bingley does. But these double standards do not change Elizabeth's opinions. She is willing to express what she believes, even when socially outclassed by both Caroline Bingley and Darcy. Furthermore, unlike Jane, Charlotte, and Caroline, Elizabeth's words and actions express the feminist idea that women should not be evaluated on the basis of material achievement, and certainly not wholly from the eyes of men.

\subsection{Les Misérables}

Some characters of Les Misérables also break class boundaries, but on a more dramatic scale than that found in Pride and Prejudice. Many, if not most, of the main characters have different social statuses by the end of the work than they did at the beginning, but two in particular are especially noteworthy: Marius and Javert. Both of these characters actually move within the socioeconomic structure-Marius falls from the aristocratic, inherited wealth of his grandfather to the relative poverty of a young revolutionary, while Javert rises to the position of a prominent officer despite being born in a prison. It would appear that, with this similarity, both men would have similar views on social mobility, class, and prejudice. In their own way, they both despised the societies they came from and changed their own character to suit a different one. However, the key difference between them is that Marius sees class structure less strictly than Javert does. Marius sees no fault in enlisting the help of those from a poorer background, as seen by his interactions with Éponine in both the original novel and in the film, but Javert appears to dislike even the idea of the poor. Perhaps Javert's views are no fault of his own - he was, to be sure, raised in a poorer household, if it could even be called a household, while Marius had all the excessive wealth and sophistry of his grandfather. Given Javert's own experiences, his beliefs should certainly not be condemned at a glance. Still, compare the ultimate fates of Javert, who 
has immediate prejudices against Fantine as she appears to be a member of the lower classes, and Valjean, who saves her even though she has no value to him. Valjean dies satisfied, but Javert throws himself into the river when he is unable to reconcile his legalist views with Valjean's later actions. These fates also highlight a central theme of the novel-the responsibility one has to his or her identity, and what experiences, ideas, or social constructs one considers to be a part of that identity. While neither Valjean nor Marius places more emphasis on socioeconomic class as a part of identity than society dictates they should, Javert considers it one of the defining characteristics of a person. In the end, Javert's heightened focus on the imagined relationships between class, identity, and morality-in other words, his reinforcement of class barriers for what he believes to be the greater good-directly results in his suicide.

\subsection{Supporting Feminists}

Also notable in both Pride and Prejudice and Les Misérables is the appearance of "supporting feminists," or characters who, through their relatively feminist views, support the development of romantic relationships. Two such characters are Mr. Bennet and Jean Valjean. Mr. Bennet values Elizabeth's mind and adventurous personality over his other daughters' beauty, reinforcing the idea that women are not simply objects of beauty. Furthermore, Mr. Bennet's only objection to Elizabeth's marriage is his "belief of [her] indifference" (Austen, 2003, p. 364). He understands his favorite daughter well, and rather than marry her off only for her wealth or for the good of the family - as his wife would perhaps have done-he understands that Elizabeth's happiness should be the only primary determinant of her marriage. Valjean, too, cares about his adopted daughter much more than many others in an age in which matrimony for women often had no more emotional significance than a contract had. By rescuing Cosette from the decrepit Thénardier inn and raising her as his own, Valjean shows her that she is worth more than the monetary or social rewards to be gained from an advantageous marriage. The feminist mindset of these two characters becomes only more pronounced when they are compared to Mrs. Bennet, who, through her pursuit of wealth-based marriage, symbolizes traditional matrimony. Mr. Bennet and Valjean are enablers, but of a different kind-only through characters like them are other characters able to express their beliefs. If happiness is a reward given by authors to their characters, then by the end of their respective works, these characters have certainly been rewarded for their actions.

\section{THE IMPACT OF FEMINISM ON RELATIONSHIPS}

\subsection{Elizabeth and Darcy vs. Jane and Bingley}

Elizabeth and Darcy as a pair are more feminist than Jane and Bingley, and yet their relationship is stronger. From the beginning, Elizabeth was never afraid to criticize or refuse Darcy, despite her awareness of his pride and his social superiority. Her boldness is evidenced not only by her declining a dance with him, but also, of course, by her refusal of his first marriage proposal. Elizabeth makes her intentions and emotions known, which ultimately results in Darcy's attraction. The proud Darcy that first proposed to Elizabeth is far different from the much more likable Darcy at the end of the book, who has changed himself as a result of Elizabeth's initial rejection. In this regard, Elizabeth wields considerable power. Her "ability to exert positive influence over one of society's most affluent men, Mr. Darcy, offers evidence for a feminist ability to subvert the male-dominated society of Regency England" (Chang, 2014, p. 76). By comparison, Caroline Bingley molds herself to fit what she believes to be Darcy's ideal romantic interest and fails to capture his love; Elizabeth changes Darcy's character and marries him. Jane, on the other hand, exhibits much more traditional values. She never speaks when she is not supposed to, and follows all the social dictates she has been taught. Women at the time were expected to moderate their emotions and not make them overt. Jane understands this norm, but she executes it too perfectly, almost losing Bingley in the process. Especially when compared to Jane's social timidity, Elizabeth's boldness allows her to attract Darcy even without her intentionally doing so. Perhaps Elizabeth herself best describes her feminist actions and Darcy's resulting love for her:

The fact is, that you were sick of civility, of deference, of officious attention. You were disgusted with the women who were always speaking, and looking, and thinking for your approbation alone. I roused and interested you, because I was so unlike them. Had you not been really amiable you would have hated me for it: but in spite of the pains you took to disguise yourself, your feelings were always noble and just; and in your heart you thoroughly despised the persons who so assiduously courted you. (Austen, 2003, p. 367) 
The true power of Elizabeth and Darcy's relationship can be attested to by the fact that the near failure of Jane and Bingley's relationship, due to Jane's conformity, was only remedied by the beginning of Elizabeth and Darcy's own relationship_-Darcy's letter.

\subsection{Elizabeth and Darcy vs. Charlotte and Collins}

The ideologies of feminism are naturally opposed to the traditional marriages of Regency England. A marriage that places more emphasis on wealth and social status inherently places less emphasis on love or a wife's happiness. While in today's world, Elizabeth's marriage is the norm, or at least the ideal, in England at the time, Charlotte's actions were much more logical and common than Elizabeth's were. Charlotte sacrifices her own opinions, her own values, and her own independence - that is to say, a part of her own identity - to abide by the social expectation of marriage for women with little future income. Her relationship with Collins is based on his imagined love for her, while the love between Elizabeth and Darcy is very much real. Darcy was attracted to Elizabeth by her "bold demeanor, unconventionality, and exceptional intelligence" (Chang, 2014, p. 79), thus demonstrating the effect that Elizabeth's feminist behavior had on Darcy. Even initially, Darcy respected Elizabethwhen she refuses him a dance, he remarks that he indeed "do[es] not dare" to despise her (Austen, 2003, p. 52), thus signaling his respect for her feminist-supported actions. In some ways, Charlotte's marriage reflects the ideals of Lady Catherine de Bourgh, who strongly believed in wealth-based marriage. However, as scholars note, "Darcy, fully conscious of his own superior station in life, cannot desist from offering marriage to Elizabeth, twice, thus demonstrating this 'faultline' in the ideology reflected by the words of his aunt" (Bajaj, 2017, p. 309). In a stunning reversal of the expectations that class structure and gender norms would suggest, Darcy apologizes to Elizabeth following his rejected proposal and goes to the length of resolving Lydia and Wickham's elopement in an effort to show his generosity to Elizabeth. This is not the proud Mr. Darcy previously known, the Mr. Darcy who so believed in maintaining social structure that he would not even dance with one of a lower class than he-this is a reformed Darcy, Elizabeth's Darcy. The foundations of these couples are highly different. As a result, the marriage between Darcy and Elizabeth is based solely on love; the marriage between Collins and Charlotte is based on anything but. If happiness is any measure at all of success, then both Caroline Bingley and Charlotte Lucas have failed, while Jane's success pales in comparison to Elizabeth's.

\subsection{Marius and Cosette}

Les Misérables as a whole may allow its characters more social mobility than Pride and Prejudice does, as Valjean and Cosette escape poverty, Marius leaves the suffocating high society to join with his revolutionary friends, and even the wealth of the Thénardiers fluctuates throughout the work. Rather than the class differences present between Elizabeth and Darcy when they become a couple, Hugo allows his young couple to stand on relatively similar footing when they fall in love. In other words, as the story of Marius and Cosette begins, they have both already broken class barriers, allowing them to avoid the pain Elizabeth and Darcy both felt when first noting the contrast between their respective social statuses. Similar to Elizabeth and Darcy, however, is the true love between Cosette and Marius. In the stage musical of Les Misérables, "A Heart Full of Love" is seen as a romantic love song, not one about financial marriage. Furthermore, in the song, Marius and Cosette are depicted as equals as each of them expresses a yearning to be with the other despite current circumstances. The timelessness and strength of their love may be seen through the song's melody, which is repeated with different lyrics in its reprise after Marius survives the barricade ordeal and Cosette reminds him of her love as he heals and mourns the death of his friends. The equality between them gender-wise is reflected through Cosette's reassurance and support of Marius:

Don't think about it, Marius!

With all the years ahead of us!

I will never go away

And we will be together

Every day. Every day

We'll remember that night

And the vow that we made.

(Hooper, 2012, para. 116)

Similar to the world of Regency England, French society at the time was highly stratified, as seen in almost every scene of both the novel and the film. Presumably, marriages were frequently made on the basis of wealth as well, but the vow of love between Cosette and Marius signifies a deviation from the traditional, male- and wealth-favoring marriage. This bond, based purely on love, gains Hugo's approval-Marius and Cosette's relationship stands the test of time, separation, and, for Marius, recovery after trauma. These lovers express feminist and anti-classist behaviors, albeit less overtly than do the characters in Pride and Prejudice. Even so, the triumph and sheer happiness of Marius and Cosette at their wedding is undeniable proof that their love is indeed a love 
that could not have formed had either one of them failed to break class barriers.

\subsection{The Thénardiers}

Interestingly, the Thénardiers appear more directly feminist in their actions than Marius and Cosette do. Despite their general lack of morals, Madame and Monsieur Thénardier are depicted as equal business partners at their inn. In the musical and film especially, not only do they have parts of equal importance in their songs, but they contribute equally to their shady business practices. While it was not uncommon for women to assist their husbands, women at the time rarely had the degree of power and influence over their husbands and their businesses as Madame Thénardier does. In the film, her assertiveness and direct cooperation with her husband demonstrates her unconventionality:

[Stage directions.] Madame Thénardier pretends to accidentally drop a comb from her hair and the customer helpfully picks it up, allowing Madame Thénardier to pick his wallet from a back pocket as he stands up. Monsieur Thénardier takes his coat which allows the couple to see the customer transfer a pocket watch from coat to jacket pocket. (Hooper, 2012, para. 37)

It is only because of this equality, the combined skills of husband and wife, are the Thénardiers able to escape punishment despite their illegal actions. In this regard, they are not like the other couples in that their feminism results in a stronger relationship, but rather it allows them to perpetuate that relationship as free members of society. Unlike Elizabeth and Darcy, they do not necessarily become happier due to their feminism, nor are they necessarily able to maintain their core values (if they have any) by not conforming to societal dictates. However, as their existence is spent just outside the bounds of legality, their ability to avoid punishment by seeking equality within their marriage is a reward in and of itself.

\section{5 Éponine and Fantine}

Finally, Éponine and Fantine, like Elizabeth and Charlotte, reflect the consequences of conformity or failing to conform. Both women are poorly treated by menÉponine is seen as a business asset rather than as a daughter by her father, and Fantine was exploited by both her lover and the Thénardiers. Fantine specifically was financially dependent on her lover, Tholomyès. Although this dependency was common in the era, Fantine is later punished for it when Tholomyès leaves her, forcing her to send her daughter elsewhere and seek employment herself. It is important to highlight the fact that the women in Les Misérables depicted as poor and unable to escape poverty-Fantine, Éponine later in the novel, and Cosette as a child - are in their position at least in part due to the actions of a man. Fantine and Cosette were abandoned by Tholomyès and lied to by the Thénardiers; Fantine was later expelled from Monsieur Madeleine's factory. While Éponine's mother doted on her as a child, her father later began to use her as a tool to satisfy his own greed. However, both women are, in a way, redeemed as they break the walls that confine them. Éponine reverses the role of class and gender by sacrificing herself for Marius; in the film, she dies in the arms of the man she loves, satisfied with her actions. Fantine, too, acts well outside of the behaviors expected of her when she spits on Monsieur Madeleine in anger. Even so, Fantine is not punished, but rescued from poverty by Monsieur Madeleine. Ultimately, their feminist actions result in their own emotional salvation.

\section{CONCLUSION}

Compared to modern society, the worlds in which Pride and Prejudice and Les Misérables were written were certainly more constricted. Socioeconomic status and gender were two major determinants of behavior, freedom, and social expectations. The fact that both Austen and Hugo reward their characters who defy these expectations may be seen as an expression of their own yearning for a more egalitarian world. Hugo was certainly no strict aristocrat, and Austen's private letters showed that she "always advised her companions to marry only on the basis of love" (Awan \& Ambreen, 2018, p. 672). At the time, such advice was strikingly different from the generally accepted view that matrimony was first and foremost a bond of wealth and reputation. Feminism features in both novels as well, albeit more prominently in Pride and Prejudice than in Les Misérables. However, neither Austen nor Hugo directly advocated for radical social reform; though both authors showed that relationships formed on the basis of feminism and class equality were stronger than those of couples who conformed, neither author made the relationship between love, feminism, and social class a major theme in their novels. Perhaps, then, it is not only feminism that resulted in the enduring strength of these relationships. If Marius, Cosette, Darcy, and Elizabeth had a chance to speak on the subject, perhaps they would comment that it is a simple 
matter of local egalitarianism, a matter of basic respect for the opinions of the significant other. After all, if the marriage of two people is the marriage of their identities, and beliefs, opinions, and behaviors constitute a significant portion of each person's identity, it only makes sense that a mutual and equal respect for each other's core values forms a bond based wholly on love.

\section{REFERENCES}

[1] Austen, Jane. (2003). Pride and Prejudice. New York, NY: Barnes \& Noble Books. (Originally published 1813)

[2] Awan, A. \& Ambreen, N. (2018, July 1). Matrimonial issues and Marxist approach in Pride and Prejudice by Jane Austen. Global Journal of Management, Social Sciences and Humanities, 4, 651-676.

[3] Bajaj, A. (2017, June 1). A study of Jane Austen's Pride and Prejudice through the Marxist lens. The Literary Herald, 3, 302-311.

[4] Bevan, T. (Producer), Fellner, E. (Producer), Hayward, D. (Producer), Mackintosh, C. (Producer), \& Hooper, T. (Director). (2012). Les Misérables [Motion Picture]. United Kingdom \& United States: Universal Pictures.

[5] Boublil, A. (Writer), Natel, J. M. (Writer), Schönberg, S. C. (Music), \& Taylor, G. (Director). (1995, October). Les Misérables: The dream cast in concert. (H. Kretzmer, English trans., lyrics). Live performance at Royal Albert Hall, London.

[6] Chang, H. C. (2014, May 1). The impact of the feminist heroine: Elizabeth in Pride and Prejudice. International Journal of Applied Linguistics \& English Literature, 3(3), 76-82. doi:10.7575/aiac.ijalel.v.3n.3p.76.

[7] Chicago Public Library. (2005). Historical context of Pride and Prejudice.

[8] Gossard, Julia. (2013). Les Misérables: A historian's review. Ex-Students Association of The University of Texas.

[9] Hooper, T. (Director). (2012). Les Misérables [Unofficial film script]. United Kingdom \& United States: Universal Pictures. Retrieved from imsdb.com/scripts/LesMiserables.html.

[10] Howard, Carol. (2004). Introduction. Pride and Prejudice, by Jane Austen (p. xiii-xxxv). Barnes \& Noble Books.

[11] Hugo, Victor. (2013). Les Misérables (L. Fahnestock \& N. MacAfee, Trans.). New York, NY: Signet Classics. (Original work published 1862)

[12] Wang, X. \& Yan, L. (2011). Analysis of the feminism in Pride and Prejudice. Theory and Practice in Language Studies, 1, 1837-1830. doi:10.4304/tpls.1.12.1827-1830. 